\title{
School organizational factors as predictors of student achievement: Principals' perspective
}

\author{
Alfred Otara ${ }^{* 1}$ Hezekiah Omolo ${ }^{1}$ \\ 1Lecturers, Department of Management and Foundations, Rongo University, Kenya \\ fredcoco2003@yahoo.co.uk; otimolo@yahoo.com \\ *Corresponding Author: fredcoco2003@yahoo.co.uk | Phone Number: +254 717413852
}

\begin{abstract}
This study aimed to deepen our understanding of how school organization factors can be used to predict students' academic performance. In particular, factors examined were leadership skills, nature of students, parental involvement and the school environment. Using stratified and simple random sampling, a total of 152 principals were selected for the study. A survey questionnaire was used to collect data whose variance and regression was analyzed using ANOVA. The findings consolidate the importance of leadership skills, nature of students, learning environment and parents in predicting students learning success. All the four aspects of school organization contributed differently to predicting students' academic performance with the Principals' Leadership Skills having the highest impact while parental involvement made the least contribution. Findings of this study are important to educational administrators to ensure a supportive learning environment for the students. In addition education authorities both at national and local levels should enhance field inspections to rate the learning atmosphere. The study also serves to contribute to the body of knowledge on school organizational factors in addition to triggering the need for more research in this domain.
\end{abstract}

Keywords: school organization; academic performance; learning environment; parents; students

\section{Introduction}

As the world keeps changing at an intense rate, institutions of learning will continue to face significant internal and external challenges (Williams,2013). Organizations are also changing dramatically, in terms of their strategies, their structures, and their systems with the aim of meeting stakeholders' expectations (Adserias et al.,2017). In modern times, change in educational organizations is affecting all stakeholders because it plays a significant role in enhancing human capital for any nation (Feenberg, 2012). In this regard, education is considered a vital first step in every human endeavor particularly in this age of globalization and technological disruptive revolution. It plays a critical role in the development of human capital and offers opportunities for better living (Battle \&Lewis, 2002). Globally, the quality of students' performance forms a critical priority for educators (Buhere, 2007). Learning organizations now need continuous renewal by redefining their strategic position in order to optimize their performance in response to emerging developments in their internal and external environment (Stavros et al., 2016). Schools, as organizational entities, are constantly being evaluated as to how well they attain their stated objectives (Mukherjee, 2013). Accordingly, administrators are increasingly being held accountable for the performance of schools.

Quality education is perceived differently making it difficult to measure (Wambui, 2015). This is because educational services take the form of transformation of knowledge, life skills and behavior modifications of learners which in themselves are not tangible (Tsinidou et al., 2010). The complexity of its process has increased due to changing attributes associated with different educators' and stakeholders' viewpoint in general (Blevins, 2009). The situation is even more complicated as parents demand better grades, society and government at large expect schools to effectively and yet economically prepare students to take their place in society. Education researchers have had an interest in investigating various variables impacting on the quality of performance of learners. These are varied and could be within and without the learning environment (Crosnoe et al., 2004).

In as much as it is now a recognized fact that access to education in terms of enrollment has improved in the recent past, achievement of learning outcomes is still wanting (UNESCO, 2015). Many students do not perform well in national examinations in many countries around the world; Kenya included(Twaweza East 
Africa, 2016; Mackatiani, 2017). One fundamental question that has pre-occupied researchers' minds for decades is why some schools perform well in examinations while others consistently perform poorly. In Pakistan, results show that almost half of the students fail in secondary level examinations (Khan, 2017). Academic performance is low among senior secondary schools in many European countries (Wijsman et al., 2016). In Nigeria, reports indicate that students do not perform well in the senior secondary certificate examinations (Filgona et al., 2017). In Kenya, the situation is not any better (Waseka et al., 2016). Scrutiny of national examination results between 2013 and 2018 shows that the majority of candidates scored lower grades. Many schools attribute this occurrence to limited resources however, emerging evidence indicates poor administrative skills, chronic teacher absenteeism and student indiscipline as the cause (Wammula, 2013; Kieti, 2017). Over 5,500 secondary schools in Kenya have limited capacity in terms of staffing, physical facilities, teaching-learning resources, and parental support to prepare their students for higher education and further training (Kieti, 2017). Poor performance has raised concern and efforts have been made to find out what factors contribute to this (Hameed \& Waheed, 2011).

School organizational factors are elements within a school setting that influence learning achievement. These include leadership, learning environment, parental engagement, and student factors. In this study, leadership skills are the practices or activities carried out by the principals of secondary schools that influence students' academic performance. They include; Administrative skills, Staff improvement, Guidance, and counseling, Supervision, Monitoring and Assessment skills (Bolanle, 2017). Student factors are the circumstances at the students' disposal which have an effect on their academic performance (Peter, 2016). These are ambition, individual efforts, and attitude on subjects (Chepkorir et al., 2014). School environmental factors are the internal surrounding of the school. These include; teaching-learning materials, IT and Teacher support, and School climate (Ayça \& Ali, 2017; Ojukwu, 2017). Parental factors are the activities or practices carried out by parents in liaison with the school to facilitate learning (Khan \& Tasneem, 2015). All these factors can be considered as organizational conditions that create a conducive atmosphere for learning (Kiplagat \&Mugaisia, 2014). They form a dynamic interrelationship between organizational structure and stakeholders bound together by a common purpose (Moswela, 2014). The interconnectedness of organizational factors is clear as to who is to do what, how, why, when, and to what extent (Cummings \& Worley, 2001).

Organizational factors that tend to influence academic performance has been of great concern and a subject of debate (Njagi, 2013). In reference to poor academic performance, a number of factors have been cited such as lack of facilities in schools, parental support, inadequate staffing, student discipline, unfavorable school and home environment (Ndiragu, 2007). Among factors that were identified by Andrews (2008) was the school plant, leadership styles of the principal, teacher characteristics and students' behavior. These factors are variables that influence learning achievement.

Despite government efforts to improve the quality of education in secondary schools like employing more teachers, increasing teachers' salaries, improving learning infrastructures through Constituency Development Funds (CDF) and provision of free textbooks, performance has largely remained low. A case in point is Migori County which has been registering a constant decline in students' performance in national examinations (Migori County Director Education office, 2018). Evidence indicates that for the last five years, the county has continued to record low mean scores in national examinations. During the period of 20132016, Migori County hardly attained a mean score of 6.0 in a 12 point score thus raising concern among researchers, stakeholders, and parents. (Migori County Director Education Office, 2018).A number of researchers have focused more on influencing factors such as school leadership, environment, teachers and parents. This study seeks to establish how school organizational factors serve as predictors of student's academic performance.

\section{Literature Review}

In as much as school organizations portend some element of uniqueness, there are elements of an effective organization that can be identified and analyzed across schools. Considerably, these elements are leadership, school environment, parental and student factors. Many factors have been attributed to students' performance including Parental education and family Social-economic level (Republic of Kenya, 2016). In Kenya, factors like inadequate school facilities, lack of active participation of students in the teachinglearning process and poor overall school atmosphere were cited as being responsible for poor performance (Twaweza East Africa, (2016). Other researchers have identified a sense of physical safety; high expectations for both academic learning and behavior (Gottfredson et al., 2005), high levels of support from administration (Petty et al., 2007) as factors that influence academic achievement. 


\subsection{Self Help Books}

Leadership is significant in developing effective performance measurement systems. It influences employees' commitment to achieving targets and improving performance. These administrators understand the complexities of the school organization and know how to make schools more effective. A key responsibility of administrators is to assist students and teachers in achieving educational goals. Principals play a significant role in school performance (Sushila, 2002). The principal is the first supervisor who ensures that effective teaching-learning is taking place (Okumbe, 2001).Success of a school depends on the principal because it is the leader that makes things done and has the ability to inspire, moderate, guide, and direct (Sermon, 2005). Students' performance depends on the principals because they control resources that influence learning (Ndunda, 2002).

Amidst all these, it is important that the principal continuously evaluate the effectiveness of his school organization. Greene \& Ross (2005) established that one of the best practices in improving student performance is by monitoring their perceptions of the learning environment. A study by Glanz (2000) on the role of school principals on performance indicated that the principal has the knowledge with respect to the business of the school such as teaching and learning in the context of change and the ongoing improvement in the school. The principal ensures that all functions of the school complement each other for the sake of learning achievement (Hill, 2006). Effective leadership from principals, influence teachers, staff teams and other sand is associated with better student performance (Seashore \& Leithood, 2010). Sergon's (2005) study on schools' success indicated that a school's success depends on principals and their management qualities. The study concluded that managing a school is like charting a ship through turbulent waters and it is through the use of right leadership skills that learning achievement can be realized. Writing on effective schools, Lezotte (2010) identified strong instructional leadership, clear and focused mission, safe and orderly schools, climate of high expectations for success, frequent monitoring of student progress, positive homeschool relations, and opportunity to learn as influential factors in learning achievement. Equally, Okello et al., (2017) noted that motivating students to achieve set goals in a school is of great concern to stakeholders. Success of a school largely depends on the principal's management practices namely; being vibrant, innovative, and being learner centered (Seashore \& Leithood, 2010). Nannyonjo (2007) in Uganda established that head teachers characteristics such as; qualifications, in-service training, age, experience together with supervision strategies and administration style influences academic achievement. Twoli (2006) on the other hand found that poor performance was influenced by students" attitudes, lack of teaching staff and students indiscipline.

\subsection{Burnout Symptoms}

Parents play an important role in students' performance. They are a source of security and encouragement (Kudari, 2016). It has been established that academic performance of students largely depends on parental involvement in their academic activities. (Barnard, 2004). In USA and Britain, factors such as the socioeconomic background of students is significant in explaining students' academic performance (Page \& Hansen, 2008). Initiatives such as parents attending open days, getting concerned and attending parentteacher association meetings, and more often engaging with principals and class teachers about how their children can enhance learners' commitments resulting in academic achievements (Jepkoech, 2002). Research has also shown that students from high social-economic families perform better than those from low levels (Garzon, 2006; Kirkup, 2008). In another study, Krashen (2005) established that students whose parents are educated score higher on standardized tests compared to those whose parents are not educated. In addition, more educated and better paid parents show greater concern for the academic progress of their children than the parents with less education and who engage in poorly paying jobs (Aduda, 2009). School management can provide guidance to parents on creating a positive home environment for improvement in learning (Marzano, 2003).

\subsection{Counseling Cognitive Behavior Therapy (CBT)}

Without students, learning institutes have no value. Student factors are the circumstances in a school or learning environment that are at the students' disposal and have an effect on their academic performance (Peter, 2016). These factors include; students' ambition, learners' individual efforts and learners' attitudes on subjects (Chepkorir et al., 2014). Others include learners' competitive spirit, discipline and school attendance (Al-Musa \& Al-Montashri, 2016). Students achievement plays an important role in quality education which is the backbone of a country (Grealish, 2012). Having clear rules and guidelines for students' behavior and setting high expectations for all is often likely to result in better performance. In secondary schools, factors such as remedial classes for students, effective instructional strategies and rewarding students help to improve performance (Nyagosia, 2011). However, Griffin's (2004) study indicates that performance depends on the students' ability and determination to achieve. Student ability in performance cannot be ignored 
(Kadenyi \& Kamuyu, 2006). Inability by students to dedicate quality time hinders academic performance (Chepchieng \& Kiboss, 2004). Whereas Mwangi's (2001) study on students' achievement found that, the major problem in determining learning achievement is attitude towards examination. All these factors clearly indicate varied variables that can predict students' academic performance.

\subsection{Environment}

School environmental factors are the internal surrounding of the school. These include; teaching-learning materials, infrastructure, teacher support, and school climate in general (Ayça \& Ali, 2017). A conducive environment enhances growth and development. Students feel happy in a peaceful and friendly environment (Ojukwu, 2017). School environment can also refer to factors within the school that influence the teaching-learning process. It includes classrooms, library, technical workshops, teachers' quality, teaching methods, peers, among other variables (Ajayi, 2001).

The school environment as a construct is complex and multi-dimensional (Collins \&Parson, 2010). It has been described as the unwritten personality and atmosphere of a school, including its norms, values, and expectations (Petrie, 2014). It is also seen as the quality and character of school life (Cohen et al., 2009). Poor learning environment has always been identified as a key factor that leads to poor performance (UNICEF, 2003). School environment remains an important area that should be well managed to enhance student academic performance (Ajayi, 2001; Kilel, 2012). The quality of education depends on teacher performance in the effective coordination of the school environment (Ajao, 2001). Most schools have insufficient facilities, poor buildings and no ventilation (Siringi, 2010). Under these conditions, the health of students and teachers may be adversely affected, which will, in turn, affect students' performance negatively (Petty\& Green, 2007). Ministry of Education of Kenya (1993) observes that besides entry grades, what matters is what goes on inside schools including positive climate, hard work by teachers and students, discipline and effective teaching. Researchers have shown that the quality of education to a large extent is dependent on the scale of equipment/facilities and the use of which they are put. These infrastructures have direct significance in students' academic performance (Kalagbor, 2016). Insufficient resources due to increased enrolment also affect learning (Onukwo, 2004). In Kenya, several schools suffer due to lack of or inadequacy of physical facilities and instructional materials (UNICEF, 2003). There has been increased enrolment resulting in overcrowded classrooms that make the work of teachers difficult (Chuma, 2012). Some studies have shown that most schools have deficient facilities, revolting buildings and no exposure to air (Suleman et al., 2012). In essence, this affects the health of learners and teachers which in turn affects students' performance. Kudari (2016) observes that for learning to be successful it should be done in a favorable environment.

In addition, improved students' relationship with teachers enhances learning and it has important implications on academic development (Nandeke et al., 2017). Teachers use resources to enhance learner's participation in in-class activities for effective learning (Klier, 2005). The resources motivate and stimulate attention and sustain learning (Agosiobo, 2007). Most of the students underperform due to school-related issues, insufficient services, and non-availability of instructional materials (Farooq et al., 2011).Good quality instructional materials can motivate interest, maintain concentration and make learning more meaningful (Asikhia, 2010). Availability of instructional materials is the most influential factor that may explain differing performance levels in schools (Ashton, 2001). Equally important is the provision of the necessary tools and equipment for a better understanding of concepts. This is in addition to practicing appropriate management policies (Maina, 2010). Other learning environmental factors such as academic emphasis, academic optimism, and strong teacher-student relationships exert a powerful impact on academic achievement (Tschannen-Moran et al, 2006; Smith \& Hoy, 2007).

It is vital that the learning environment should be characterized by discipline order with amiability and co-operation among teachers and students (Kudari, 2016). Large class size makes monitoring of students' attendance very difficult and hinders the provision of quality feedback to learners (Bascia, 2003). It is important for students to feel valued and wanted in order for them to achieve academic success (Price, 2008). Schools must foster an environment that is positive and effective (Earthman \& Lemaster, 2009). Schools that do not offer the basic comforts for teachers and students deter effective learning (Earthman \& Lemaster, 2009). When the environment is safe, teachers and students feel comfortable and focus more on learning (Earthman \& Lemasters, 2009).The atmosphere of a school has to be one that is supportive and caring (Littky \& Grabelle, 2004). The school environment, therefore, must morph into places where everyone is safe, valued, and desire to attain academic growth.

\section{Materials and Methods}

Descriptive survey research design was used to explore and determine how school organizational factors predict students' academic performance in public secondary schools. The design was appropriate in 
capturing opinions of principals and students (Creswell, 2014). The study focused on public secondary schools in Migori County which has been posting relatively low grades in the Kenya Certificate of Secondary Education results. Population was composed of 245 principals. Mukherjee (2013) notes that Principals carry out a lot of tasks that directly impact performance. These tasks include monitoring of students and teachers, execution of students' assessment, delegation of duties and responsibilities, incorporating guidance and counseling programs in schools, uniting teaching and non-teaching staff (Akinola \& Obafemi, 2013), and supervisory and discipline (Micheal et al., 2016). The Principal is the main link between parents and the school and the way he/she performs in this capacity largely influences the attitudes of the parents and students towards the school (Seashore \& Leithood, 2010).

Schools were organized according to sub-counties following the records obtained from the Teachers Service Commission, Migori County director's office, 2018. A sample of 152 principals making 62 percent of the population was considered adequate based on a table designed by Krejcie and Morgan (1970). Simple random sampling was then used to get principals who participated in the study. Principals were considered important respondents in this study because they are the custodian of school information and the implementers of government policies. Most of the data gathered in this study were documentary at the purview of principals who are the only legal authority in providing school information. Principals are able to account for records about students' performance, parental engagement as captured in the parent journals, and school performance in general.

A five-point Likert scale questionnaire was used to gather information regarding how best leadership skills, student factors, school environmental factors, and parental factors predict students' academic performance. The questionnaire was structured according to principles advanced for questionnaires construction by (Fraenkel\&Wallen, 2009). Characteristics of variables that informed the questionnaire were drawn from the literature review. Principal's leadership skills include administrative skills, staff improvement, guidance and counseling and supervision (Onyara, 2013; Modo et al., 2013). Aspects of student factors such as students' focus and attitude, discipline and drug abuse, and involvement in cocurriculum activities were studied (Peter, 2015; Chepkorir et al., 2014). School environmental factors were; teaching and learning materials, use of Educational Technology and school climate (Ayça \& Ali,2017; Ojukwu, 2017). Parental factors such as education level, Parental involvement/follow-up, and Parental socio-economic status were considered (Chowa et al., 2013; Khan \& Tasneem, 2015).

Consequently, the questionnaire was ideal because it facilitated large coverage and collection of data after establishing its validity and reliability.Face and content validity is defined as the subjective agreement amongst professionals that a scale logically seems to reflect accurately what it purports to measure (Bryman, 2012). In this case face and content validity were determined by presenting the questionnaire to three experts in Educational Administration for scrutiny and advice. They evaluated the relevance of the content of all items in the questionnaire in reference to the central research question and revised the final version.

To ensure internal consistency, the reliability coefficient of the questionnaire was obtained by computing Cronbach's alpha using Statistical Package for Social Sciences (SPSS). A Cronbach's alpha coefficient of 0.86 , was obtained from a consideration of internal consistency of the four sub-scales which were principals' leadership skills, student-based factors, school environmental factors, and parental involvement. This measure was important because it provides information about the relationships between individual items in the scale (Oso \& Onen, 2009). A 5-point rating scale of $1=$ very low influence $=2=$ Low influence, 3 = Moderate influence, $4=$ High influence, 5 = Very high influence was used. Scores obtained on a given aspect were totaled to give the aggregate score per item before calculating the means. The mean ratings were then interpreted in agreement with Cheruiyot \&Simatwa (2016) classification, using intervals as follows: $1.00-1.44=$ very low, $1.45-2.44=$ low, $2.45-3.44=$ moderate, $3.45-4.44=$ high and $4.45-5.00=$ very high.

In measuring each component, questionnaire items were combined as follows to compute numeric values: Principal's leadership skills had 12 items which included: Students and teachers monitoring; execution of students' assessment; delegation of duties and responsibilities; incorporating guidance and counseling programs in schools; uniting teaching and non-teaching staff; initiating teamwork among the teaching staff; monitoring students' discipline; quality improvement measures; communication and listening skills; mobilizing of adequate staffing; Coordination, supervision, and training on managerial skills. Student factors had 10 items including students' ambition; learners' individual effort; learners' attitude on subjects; learners' competitive spirit; learners' own set targets; students' unrest and absenteeism from school; Students' discipline in school and Participation in co-curricular activities. School environmental factors comprised 10 items consisting of Peer influence; School security; Presence of internets and other electronics; trained and experienced teachers; teachers' financial motivation; library; laboratory and instructional materials. Lastly, Parental factors had 7 items, comprising of the education level of parents; communication between parents and teachers; regular checks by parents on academic performance; the attitude of parents 
towards their children; parental homework support; parental investment of financial resources in their children's education and parental academic socialization.

In the analysis, linear regression was used to measure or ascertain how much independent variables influencedthe dependent variable. ANOVA was used to show whether the independent variable was a significant predictor of the dependent variable. Finally multiple regressions were used to establish a linear model in order to investigate how well the set of the independent variables were able to predict academic performance. It was also important in interpreting the relative contribution of each of the variables and in establishing how much unique variance in the dependent variable was occasioned by the independent variables. All tests of significance were computed at $\alpha=0.05$.

\section{Results and Discussions}

Normality and dependence of the data

Normality of the data was tested by the use of formal test using Kolmogorov-Smirnov and Shapiro-Wilk tests, as shown in Table 1.0.

Table 1.0 Tests of Normality

\begin{tabular}{|c|c|c|c|c|c|c|}
\hline \multirow[b]{3}{*}{ Principals' Leadership Skills } & \multicolumn{3}{|c|}{ Kolmogorov-Smirnova } & \multicolumn{3}{|c|}{ Shapiro-Wilk } \\
\hline & Statistics & $\mathrm{df}$ & Sig. & Statistic & Df & Sig. \\
\hline & .084 & 116 & .044 & .963 & 116 & $.063^{*}$ \\
\hline Students' Factors & .098 & 116 & $.068^{*}$ & .979 & 116 & .070 \\
\hline School Environmental Factors & .119 & 116 & $.090^{*}$ & .981 & 116 & $.094^{*}$ \\
\hline Parental Involvement & .122 & 116 & $.070^{*}$ & .933 & 116 & $.080^{*}$ \\
\hline Students' Academic Performance & .116 & 116 & .041 & .956 & 116 & .051 \\
\hline
\end{tabular}

*. This is a lower bound of the true significance.

a. Lilliefors Significance Correction

The table shows both Kolmogorov-Smirnov (K-S) and Shapiro-Wilk test results. In the interpretation, a significantly $(\mathrm{p}<.05)$ smaller $\mathrm{W}$ than 1 means that the normality is not met. Hence, the data is normal when Shapiro-Wilk (W) is significantly greater than .05. It is evident from Table 1.0 that all the variables met the normality condition $(P>.05)$; there were no statistically significant differences noted in any of the variables with their corresponding normal scores. Durbin Watson test was used to investigate whether observations were independent as one of the assumptions of multiple regression as shown in Table 2.0.

Table 2.0 Test of Independence: Model Summary

\begin{tabular}{|c|c|c|c|c|c|}
\hline Model & $\mathrm{R}$ & R Square & Adjusted R Square & $\begin{array}{l}\text { Std. Error of the } \\
\text { Estimate }\end{array}$ & Durbin-Watson \\
\hline 1 & $.584^{\mathrm{a}}$ & .341 & .317 & 1.37734 & 1.641 \\
\hline
\end{tabular}

Based on Marquardt (2012), if there is no autocorrelation, then the subsequent observations are related, the Durbin-Watson statistic should be between 1.5 and 2.5. Table 2.0 shows that the Durbin-Watson statistic was 1.641 which is between 1.5 and 2.5, denoting that the data was not auto-correlated, meaning the assumption of independence was not violated.

\subsection{Multiple Regression Analysis}

The study sought to establish a linear model that could be used to describe the optimal level of students' academic performance inputting school-related factors. This was done by use of standard multiple regression analysis, where all the independent variables which had statistically a significant contribution to the model were factored in the regression at once. The multiple regressions helped to investigate how well the set of independent variables was able to predict the level of students' academic performance and it provided information about the relative contribution of each of the variables that make up the model. Equally, each independent variable was evaluated in terms of its predictive power, over and above that offered by all the other independent variables. It enabled the researcher to know how much unique variance, in the dependent variable was explained by each predictor. Table 3.0 shows the regression analysis model summary output. 
Table 3.0 Regression Analysis Model summary output: School organizational Factors on Students' Academic Performance.

\begin{tabular}{|c|c|c|c|c|c|c|c|c|c|}
\hline \multirow[b]{2}{*}{ Model } & \multirow[b]{2}{*}{$\mathrm{R}$} & \multirow[b]{2}{*}{ R Square } & \multirow[b]{2}{*}{$\begin{array}{c}\text { Adjusted R } \\
\text { Square }\end{array}$} & \multirow{2}{*}{$\begin{array}{l}\text { Std. Error of } \\
\text { the Estimate }\end{array}$} & \multicolumn{5}{|c|}{ Change Statistics } \\
\hline & & & & & $\begin{array}{l}\text { R Square } \\
\text { Change }\end{array}$ & F Change & df1 & df2 & Sig. F Change \\
\hline 1 & $.580^{\mathrm{a}}$ & .336 & .318 & 1.37633 & .336 & 18.912 & 3 & 113 & .000 \\
\hline
\end{tabular}

a. Predictors: (Constant), Parental Involvement, Principals' Leadership Skills, School Environmental Factors, Student Factors.

Findings show that there is a good measure of the level of prediction of the dependent variable -students' academic performance, as signified by Adjusted $R=.318$. The value of Adjusted $R$ Square (.318) translated to percentage show that school organizational factors alone accounted for $31.8 \%$ of the variance in secondary school students' academic performance. This is the proportion of variance in the students' academic performance explained by the school organizational factors. In other words, it is the proportion of variation accounted for by the regression model above and beyond the mean model. However, to assess the statistical significance of the result it was necessary to look at the ANOVA results shown in table 3.1

Table 3.1: ANOVA-School Organizational Factors on Students' Academic Performance.

\begin{tabular}{llccccc}
\hline & Model & Sum of Squares & Df & Mean Square & F & Sig. \\
\hline \multirow{2}{*}{1} & & & 4 & 35.825 & 18.912 & $.000^{\mathrm{b}}$ \\
\cline { 2 - 7 } & Regression & 107.474 & 112 & 1.894 & \\
\cline { 2 - 6 } & Residual & 212.158 & 116 & & \\
\hline
\end{tabular}

a. Dependent Variable: Students' Academic Performance

b. Predictors: (Constant), Parental Involvement, Principals' Leadership Skills, School Environmental Factors, Student factor

It is evident from the ANOVA results that the model reached statistical significance $[F(3,112)=18.912$, Adjusted $\mathrm{R}^{2}=.318$, sig. $<.05$ ], implying that the model was significant and adequate enough to explain the variance in Students' Academic Performance among public secondary schools. In other words, the results show that the school organizational factors significantly predict students' academic performance, meaning the regression model is a good fit of the data.

\subsection{Evaluating Contribution of each of the Predictor}

The study sought to investigate the level of contribution of the individual organizational factors within the model in the prediction of students' academic performance. This is shown by coefficients values in Table 4.0.

Table 4.0: Coefficient Output: School organizational Factors on Students' Academic Performance

\begin{tabular}{|c|c|c|c|c|c|c|}
\hline & \multirow[t]{2}{*}{ Model } & \multicolumn{2}{|c|}{ Unstandardized Coefficients } & \multirow{2}{*}{$\begin{array}{c}\text { Standardized } \\
\text { Coefficients } \\
\text { Beta }\end{array}$} & \multirow[t]{2}{*}{$\mathbf{T}$} & \multirow[t]{2}{*}{ Sig. } \\
\hline & & $\mathrm{B}$ & Std. Error & & & \\
\hline \multirow{5}{*}{1} & (Constant) & -2.621 & 1.153 & & -2.273 & .025 \\
\hline & Student Factors & .593 & .248 & .197 & 2.512 & .026 \\
\hline & Principals' Leadership Skills & .782 & .179 & .363 & 4.363 & .000 \\
\hline & School Environmental Factors & .662 & .250 & .226 & 2.648 & .009 \\
\hline & Parental Involvement & .581 & .245 & .193 & 2.367 & .020 \\
\hline
\end{tabular}

a. Dependent Variable: Students' Academic Performance

$\mathrm{Y}=\boldsymbol{\beta}_{\mathrm{o}}+\boldsymbol{\beta}_{1} \mathrm{x}_{1}+\boldsymbol{\beta}_{2} \mathrm{x}_{2}+\boldsymbol{\beta}_{3} \mathrm{x}_{3}+\boldsymbol{\beta}_{4} \mathrm{x}_{4}+\varepsilon$.

-2.621 units $+.593 \mathrm{x}_{1}$ units $+.782 \mathrm{x}_{1}$ units $+.662 \mathrm{x}_{3}$ units $+.581 \mathrm{x}_{4}$ units + error term

From the model, it is evident that all four aspects of school organizational factors contributed differently to predicting students' academic performance. For instance, out of the four predictors factored in the regression equation, Principals' Leadership Skills had the highest impact on enhancing students' academic performance, while parental involvement made the least contribution in explaining the variability of the model. The variable "Principals' Leadership Skills" had the largest beta coefficient of .363 ( $p<.05)$, implying that it made the strongest unique contribution to explaining the dependent variable. This means that a one standard deviation improvement in Principals' Leadership Skills leads to a .363 standard deviation increase in predicting students' academic performance, with the other variables held constant.

On the contrary, the beta value for parental involvement was the lowest at .193, indicating that it made the least contribution to the model; a one standard deviation increase in student factors would only lead to a .193 standard deviation increase in student academic performance, with the other variables in the model held constant, however, this effect was significant [p=.020]. It is evident that all the variables made a 
statistically significant $(\mathrm{p}<.05)$ unique contribution to the regression model, except student factors which was not included in the model.

It was noted that the total Adjusted R squared value for the model (.318 or 31.8\% explained variance) did not equal to the sum of the Adjusted R Squared for each variable. This was because the part correlation values represented only the unique contribution of each variable, with any overlap or shared variance removed. The total Adjusted $\mathrm{R}$ squared value, however, included the unique variance explained by each school organizational factor. The predictors were positively correlated (shown by zero-order correlations) hence there was a lot of shared variance that were statistically removed when they were all included in the model.

\subsection{The regression model}

A regression model for the relationship between these independent variables and the dependent variable is shown below.

In this model: $\mathrm{Y}=\boldsymbol{\beta}_{\mathrm{o}}+\boldsymbol{\beta}_{1} \mathrm{x}_{1}+\boldsymbol{\beta}_{2} \mathrm{x}_{2}+\boldsymbol{\beta}_{3} \mathrm{x}_{3}+\boldsymbol{\beta}_{4} \mathrm{x}_{4}+\varepsilon$.

Where: $\mathrm{Y}$ is Students' Academic Performance
$\mathrm{X}_{1} \quad$ Student Factors
$\mathrm{X}_{2} \quad$ Principal's Leadership Skills
$\mathrm{X}_{3} \quad$ School Environmental Factors
$\mathrm{X}_{4} \quad$ Parental Involvements

Optimum level of students' academic performance was presented by:

-2.621 units $+.593 \mathrm{x}_{1}$ units $+.782 \mathrm{x}_{1}$ units $+.662 \mathrm{x}_{3}$ units $+.581 \mathrm{x}_{4}$ units + error term

From the model, the coefficients indicate how much students' academic performance varies with an independent variable when the other two independent variables are held constant. For example, the unstandardized coefficient, $X_{2}$, for principal's leadership skills which is equal to .782 means that for each one unit improvement in the leadership skills, there is a corresponding improvement in student's academic performance in public secondary school of.782 units. All the predicators, in the model, had a unique significant contribution to the model. Therefore, it is concluded that the model was adequate to predict student academic performance. The model was statistically significant $\left[F(3,112)=18.912\right.$, Adjusted $R^{2}=.318$, sig. < .05], implying that it was adequate to predict students' academic performance. About $32 \%$ of the variability in student academic performance is explained by the school organizational factors. However, other factors (not covered in this regression model) account for about $68 \%$ of the model.

Empirical evidence confirms that among other factors, the school climate is powerful in affecting students' academic achievement (Chen \&Weikart, 2008).School environment is a strong predictor of students' emotional and behavioral outcomes (Brand et al., 2008). It affects students' adaptive psychosocial adjustment and self-esteem (Way et al., 2007). Bernstein (2006) study reveals that, in the United States of America, students who attend well-maintained schools with good classrooms have a higher achievement than those who attend poorly maintained schools. It is evident from the findings that school organizational factors are critical in predicting students' performance. This revelation concurs with other previous studies in various ways. The consequences of failed school leadership skills are grave and lead to poor academic achievements of the learners (Kalagbor, 2016). Accordingly, possession of technical, interpersonal, conceptual and administrative skills is crucial in school academic performance (Akinola \& Obafemi, 2013). Further, principals who adopted quality improvement measures by applying the right leadership skill influenced learning achievement greatly (Oluremi, 2013). Arguably, principals with relational leadership skills focus on the satisfaction, motivation and general well-being of team members which encourages school academic performance (Ojukwu, 2017).

Findings of student factors as predictors of academic performance are supported by (Ali et al., 2014; Ayça\& Ali, 2017) who indicated that there is a significant relationship between the nature of students in terms of attitude and academic performance. Gitome et al., (2013) also affirmed the same in their study which confirmed that students differed in terms of their mastery based on the attitude formed by the students on the subject. School environmental factors are equally significant. Studies show that students from a school with adequate facilities, good teachers and favorable environment perform well than those from schools with fewer facilities, unqualified teachers and the less enabling environment (Mudasir \&Norsuhaily, 2015; Ilomo \& Mlavi, 2016). In addition, there is a notable difference between the mean performance of students taught in an ideal learning environment and that of those taught in a dull environment (Ado, 2015).Lastly, the role of environmental factors cannot be underestimated. Frequent teacher-family communication affects students' academic achievement as demonstrated (Lee, 2014). In the same vain, parent-child and parent-school involvement practices differentially influence student attitude and behaviors thus affecting their learning achievement (Ralphand \& McNeal, 2014). 


\section{Conclusions}

Educational organizations need to think about the future and by extension their relevance. There are numerous factors that determine successful performance of organizations. Every organization has its success performance factors at varied measures. An educational organization is deemed to be effective when it achieves the expected output which is students' achievement. This can only be understood by clearly identifying critical predictors of success. There is a number of factors within the school organization that affects academic performance of the students. This includes leadership skills, school learning environment, parental involvement, and student factors. Whereas many previous studies have mainly focused on school factors in isolation, this study treated them as a package by demonstrating how they together impact student academic performance. It also shows how the principal leadership skills take a center stage in enhancing learning by ensuring all the other organization factors are given due attention. This study clearly shows that these factors have a significant amount of influence on students' academic achievement. Since the regression model was found to be a good fit for the data, it implies that the factors could be used to predict students' academic performance.

It is vital for the students to be dedicated and sincere towards their studies. The learning environment should be peaceful and amiable and teachers should be facilitative in the entire process of learning. The ultimate aim of academic success can be attained within the school organization if principals are able to utilize appropriate leadership skills in pulling different strands together. It is therefore recommended that school authorities should continuously evaluate their leadership skill, ensure that there is a supportive learning environment for the students, assess the nature and capabilities of learners, and keep parents engaged. In addition education authorities both at national and local levels should enhance field inspections that are more focused in all the four organizational factors for better learning. This would improve an understanding of these important factors that if well managed and nurtured can be used to predict the future performance of students.

\section{References}

Ado, S. T.(2015).Influence of Learning Environment on Students' Academic Achievement in Mathematics: A Case Study of Some Selected Secondary Schools in Yobe State - Nigeria. Journal of Education and Practice, 6(34), 40-44.

Aduda, D. (2009, March 4). Top Marks for Alliance, p.1. Daily Nation. Nairobi: Nation Media Group Limited.

Adserias, R.P., Charleston, L.J., \& Jackson, J.F. (2017). What style of leadership is best suited direct organizational change to fuel institutional diversity in higher education? Race ethnicity and education, 20(3), 315-331

Agosiobo, C. (2007). Effective Teaching in Schools: Theory and Practise 2nd Edition. Deltal Place: Stanley Thornes Ltd.

Ajao, A. (2001). Teachers effectiveness on students' academic performance. Journal of Education and Practice 5 (22), 2-17

Ajayi, M. A. (2001).Effect of learning environment on students' academic achievement in Lagos States secondary schools. Unpublished MED thesis University of Nigeria.

Akinola, O., \& Obafemi, B. (2013). Principals' leadership skills and School effectiveness: The case of South Western Nigeria. WorldJournal of Education,3(5), 27-33. doi:10.5430/wje.v3n5p26

Ali, A., Dada, I., Isiaka, G., \& Salmon, S. (2014). Types, Causes and Management of Indiscipline Acts among Secondary School Students in Shomolu Local Government Area of Lagos State. Salmon, S.A.4(14), 253264.

Al-Musa, H., \& Al-Montashri, S. S. (2016). Substance abuse among male secondary school students in Abha City, Saudi Arabia: Prevalence and associated factors.Eastern Mediterranean health journal, 27(4), 808812

Andrews, C. (2008). Add parents, subtract confusion. Times Educational Supplement, 4770:56-57.

Asikhia, O. A. (2010) Students and Teachers' Perception on the Causes of Poor performance in Ogun state secondary schools (Nigeria) Implication for Counseling for National Development. In the European Journal of Social Sciences, 13 (2), 229-242

Ashton, C. (2001). Life Skills Project Implementation in the American Education System. YAREVAN: UNICEF.

Ayça, S. A., \& Ali, A. T. (2017).The role of physical environmental factors on university students' academic performance. Journal of Human Sciences, 14(4), 4241-4250

Battle, J., \& Lewis, M. (2002). The increasing significance of class: The relative effects of race and socioeconomic status on academic achievement. Journal of Poverty, 6(2), 21-35.

Barnard, W. M. (2004). Parent involvement in elementary school and educational attainment. Children and Youth Services Review, 26, 39- 62. 
Bernestein, J. (2006). State of Working America Cited in Stieglitz, Joseph E. (2012-06-04). The prince of inequality: How Today's Divided Society Endangers our Future. Ithaca, NY: ILR Press.

Bascia, B. (2003).Achieving Universal Primary Education by 2015. A chance for every child. Washington DC: World Bank

Blevins, B. M. (2009). Effects of socioeconomic status on academic performance in Missouri public schools. Retrieved from http://gradworks.umi.com/3372318.pdf

Bolanle, A. O. (2017). Principals' leadership skills and school effectiveness: The case of South Western Nigeria. World Journal of Education, 3 (5), 27-33. doi:10.5430/wje.v3n5p26

Brand, S., Felner, R. D., Seitsinger, A., Burns, A., \& Bolton, N. (2008). A large scale study of the assessment of the social environment of middle and secondary schools: the validity and utility of teachers' ratings of school climate, cultural pluralism, and safety problems for understanding school effects and school improvement. J. Sch. Psychol, 46, 507-535. doi: 10.1016/j.jsp.2007.12.001

Buhere, P. (2007). A study of Quality of Education in Public Secondary Schools in Bungoma Division of Bungoma District.Unpublished MED Project, University of Nairobi.

Chepchieng, A., \&Kiboss.P. (2004). Recruiting Retaining and Retraining Secondary Schools. Teachers and Principals in Sub - Saharan African: Secondary Education in Africa. Thematic Study No. 4. Ireland: World Bank

Chen, G., \& Weikart, L. A. (2008). Student background, school climate, school disorder, and student achievement: an empirical study of New York City's middle schools. J. Sch. Violence 7, 3-20. doi: 10.1080/15388220801973813

Chepkorir, S., Cheptonui, E. M., \&Chemutai, A. (2014).The relationship between teacher-related factors and students attitudes towards secondary school chemistry subject in Bureti district, Kenya. Journal of Technology and Science Education, 4(4), 1-9

Chowa, G., Masa, R., \& Tucker, J. (2013). The effects of parental involvement on academic Performance of Ghanaian youth: Testing measurement and relationship using structural equation modeling. Children and Youth Services Review, 35(12), 2020-2030.

Chuma, P. C. (2012). Challenges Affecting Teaching-Learning in Primary Schools in Kenya. A case study of Central Division Mandera East District. Executive Med Project, Moi University.

Collins, T. N., \&Parson, K. A. (2010). School climate and student outcomes. J. Cross Discipline. Perspect. Educ. 3, 34-39.

Cohen, J., Pickeral, T., \& McCloskey, M. (2009). Assessing school climate. Educ. Digest. 74, 45.

Creswell, J. W. (2014). Research Design Qualitative, Quantitative and Mixed Methods Approaches (4th ed.). Thousand Oaks, CA: Sage Publications

Crosnoe, R., Johnson, M. K., \& Elder, G. H. (2004). School size and the interpersonal side of education: An examination of race/ethnicity and organizational context. Social Science Quarterly, 85(5), 1259-1274.

Cummings, T. G. \& Worley, C. G. (2001). Organization Development and Change $7^{\text {thed }}$. Ohio: South Western College Publishing.

Earthman, G. I., \& Lemasters, L. K. (2009). Teacher attitudes about classroom

conditions. Journal of Educational Administration, 47(3), 323-335. doi:10.1108/09578230910955764

Farooq, M. S., Chaudhry, A. H., Shafiq, M.,\& Berhanu, G. (2011). Factors affecting students' quality of academic performance: a case of secondary school level. Journal of

quality and technology management 7(2), 1-14.Feenberg, A. (2012).

Questioning technology: Routledge.

Filgona, J., Filgona, J., \& Sababa, L. K. (2017). Mastery Learning Strategy and Learning Retention: Effects on Senior Secondary School Students' Achievement in Physical Geography in Ganye Educational Zone, Nigeria. Asian Research Journal of Arts \& Social Sciences, 2(3), 1-14.

Fraenkel, J. R.,\& Wallen, N. E. (2009). How to Design and Evaluate Research in Education (7thed.). New York: McGraw-hill.

Gitome, J.W., Katola, M.T., \& Nyabwari, B.G. (2013). Correlation between students' discipline and performance in the Kenya Certificate of Secondary Education. International Journal of Education and Research, 1(8), 1-10.

Glanz, J. (2000). Paradigm debates in curriculum and supervision: Modern and postmodern perspectives. Westport, CT: Bergin and Garvey.

Gottfredson, G. D., Gottfredson, D. C., Payne, A. A., \& Gottfredson, N. C. (2005). School climate predictors of school disorder: Results form a national study of delinquency prevention in schools. Journal of Research in Crime \& Delinquency, 42(4), 412-444.

Greene, M. B., \& Ross, R. (2005). The nature, scope and utility of formal laws and regulations that prohibit schoolbased bullying and harassment. Paper presented at the Persistently Safe Schools 2005: The National Conference of the Hamilton Fish Institute on School and Community Violence. 
Grealish, L. (2012). How competency standards became the preferred national technology for classifying nursing performance in Australia. Australian Journal of Advanced Nursing. 30(2), 20-34.

Griffin, G. (2004). Issues that KCSE results should raise. The Educational insight. Issues 07 p24.

Hameed, A.,\& Waheed, A. (2011). Employee development and its effect on employee performance: A conceptual framework. International Journal of Business and Social Science, 2(13),224-229.

Hill, P. (2006). Put learning first: A portfolio approach to public schools. Washington, DC: Progressive

Ilomo, O., DR., \&Mlavi, B. (2016).The Availability of Teaching and Learning Facilities and Their Effects on Academic Performance in Ward Secondary Schools in Muheza - Tanzania.International journal of education and research, 4(6).571-582

Jepkoech, S. (2002). A survey of factors that influence the performance of students in Economics in KCSE: A Case of selected schools in Rift Valley Province of Kenya. Unpublished M.Phil.Thesis.Moi University, Eldoret, Kenya.

Kalagbor, L. D. (2016). An Analysis of Factors Influencing Students' Academic Performance in Public and Private Secondary Schools in Rivers State-Nigeria. Journal of Education and Practice,7(28), 96-101

Kadenyi, N., \&Kamuyu, D. (2006). Introduction to Educational Research.Njoro.Egerton University.

Khan, N. (2017, February). Pakistan Education Statistics. Islamabad, Pakistan: AEPAM.

Khan, R.M.A., Tasneem, N.I.S. (2015). the influence of Parents Educational level on Secondary School Students Academic achievements in District Rajanpur. Journal of Education and Practice, 6 (16), 143-150.

Kieti, D. (2017). Community Based Tourism Initiatives: Lessons for Best Practice in Sub-Saharan Africa. In Jones, E. \& Wishitemi, B. E. (eds). Tourism Planning, Policy Formulation and Community Based Tourism. Eldoret, Kenya: Moi University Press, p. 62-71.

Kilei, J. K. (2012).Factors Influencing Quality Training in Public Primary TTC in Rift Valley Zone, Kenya. Executive Med project, Moi University

Kiplagat, W.S, \& MUGASIA, F. A. (2014). School Factors Associated with Student Violence in Secondary Schools in Nandi South District, Kenya. International journal of humanities and social sciences,4(1), 123132.

Kirkup, J. (2008). Middle-class children resentful at being pushed to succeed. Telegraph. Retrieved from http://www.telegraph.co.uk/education/3330301/Middleclass- children- resentful-

atbeing-pushed-to-succeedpoll-shows.html

Klier, A. (2005).Girls and Schools in Sub-Saharan Africa: From Analysis to Action. Washington DC: World Bank.

Krashen, S. (2005). The hard work hypothesis: Is doing your homework enough to overcome the effects of poverty? Multicultural Education, 12(4), 16-19.

Krejcie, R.,\& Morgan, D. (1970). Determining Sample Size for Research Activities. Educational and Psychological Measurement. An electronic Journal for the 21st Century. Available at: http://www.emoderators.com/ipct-j/1998/n3-4/hill.hmtl

Kudari, J.M. (2016). Survey on the Factors Influencing the Student's Academic Performance. International Journal of Emerging Research in Management and Technology, 5(6), 30-36.

Lee, J.S. (2014). The relationship between student engagement and academic performance: Is it a myth or reality? The Journal of Educational Research, 107(3), 177-185.

Lezotte, L. W. (2010). What effective schools do: Re-envisioning the correlates. Indianapolis, IN: Solution Tree.

Lioyd, C. B., Mensch, B. S., \& Clark, W. (2000). The effects of primary school quality on school dropout among Kenyan girls and boys.Comparative Education Review, 44, 113-47.

Littky, D., \& Grabelle, S. (2004). The BIG picture: Education is everyone's business. Alexandria, VA: Association of Supervision and Curriculum Development.

Mackatiani, C. I. (2017). Influence of examinations oriented approaches on quality education in primary schools in Kenya. Journal of education and practice, 8(14), 51-58

Maina, M.J. (2010). Strategies Employed by Secondary School Principals to Improve Academic Performance in Embu West District. Kenyatta University. Retrieved April 25, 2018 from http://irlibrary.ku.ac.ke/bitstream/handle/123456789/930/Mwaura\%2C\%20James\%20 Maina.pdf?sequence $=3$

Marzano, R. J. (2003). What works in schools: Translating research into action? Retrieved from http://pdonline.ascd.org/pd_online/whatworks/marzano2003_ch13.html

Marquardt, M. J. (2012). Building the Learning Organization; Achieving Strategic Advantage through a Commitment to Learning ( $3 r d$ Ed.). Nicholas Brealey Publishing: Boston, USA.

Micheal, D., Babatola, J., \&Olabisi, R. (2016). Principals' Administrative Strategies

Model for Educational Reform. Retrieved from https ://files.eric .ed.gov / fulltext /ED375485.pdf

Migori County Education Director Office (2018). Examination results. Migori, Kenya

Ministry of Education (1993). Report of a Conference on Educational

Administration, Nairobi; Jomo Kenyatta Foundation.

Modo, F., Uwah, C., \&Mogbo, I. (2013). Guidance and Counseling Services in Secondary School as Coping 
Strategy for Improved Academic Performance of Students in Akwalbom State, Nigeria, 3, 4th ser.Research on humanities and social sciences. 3(4), 43-49

Moswela, B. (2014). Students' Academic Achievement: Whose Responsibility and Accountability? International Journal of Business and Social Science, 5(10), 47-57.

Mudassir, I. U., \&Norsuhaily, A. B. (2015).The Influence of School Environment on Academic Performance of Secondary School Students in Kuala Terengganu, Malaysia.252-256.

Mukherjee, S. (2013). A study of the managerial skills of school principals and performance of schools. Journal of Indian Research, 1(2), 81-86.

Mwangi, J.K. (2001). .Determinants of learning Achievement in Economics in Kenyan

Secondary Schools. Unpublished Ph. D Thesis. University of Nairobi.

Nannyonjo, H. (2007). Education Input in Uganda: An Analysis of Factors Influencing Learning Achievement in Grade Six. Washington DC: World Bank.

Nandeke, E., Chumba, S. K., \&Kiprop, C. (2017).Rethinking of Public Secondary Schools Discipline in Kenya. European Scientific Journal, 13 (19).

Ndirangu, P. (2007). An investigation of the relationship between test anxiety and academic performance in secondary schools in Nyeri district, Kenya.

Nakuru. Egerton University.

Ndunda, P. (2002). An Investigation into the Probable Factors Responsible for Poor Performance in KCSE in Vihiga District of Western Province. Master of Education Project, KU: Unpublished

Njagi, L. W. (2013). Teacher Factors Influencing Students' Academic Achievement in Secondary Schools. International Journal of Education and Research, 1(3), 1-14.

Nyagosia, P.O. (2011). Determinants of Differential Kenya Certificate of Secondary Education Performance and School Effectiveness in Kiambu and Nyeri Counties, Kenya. Kenyatta University.

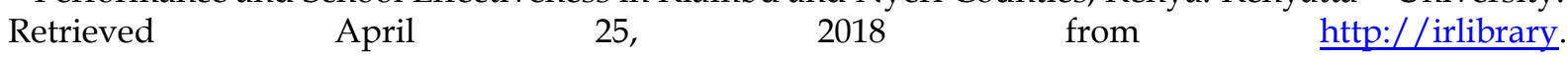
ku.ac.ke/bitstream/handle/123456789/3009/Nyagosia,\%20Patrick\%20Ogecha. pdf?sequence $=3$

Ojukwu, M. (2017).Effect of Insecurity of School Environment on the Academic Performance of Secondary School Students in Imo State.International Journal of Education \& Literacy Studies. 5(1), 20-28.51-55.

Okello, L.M., Sichari, M. \& Odera, F. (2017).Influence of School Environmental Characteristics on Retention of Secondary School Teachers in Homa Bay County of Kenya. International Journal of Academic Scientific Research, 5(1), 237-246.

Okumbe, J. A. (2001) Educational Management Theory and Practice. Nairobi: Nairobi University Press.

Oluremi , F. (2013). Principals Organizational Management and Students' Academic Achievement in Secondary Schools in Ekitistate Nigeria, Singaporean journal of business economics and management studies, $2(2), 78-84$.

Onukwo, G. (2004/2005). Class note on educational psychology, in p. g. d. i. education (Ed.).

Onyara, N. B. (2013). School Based Factors Influencing Student's Academic Performance at Kenya Certificate of Secondary Education in Teso South District.International journal of education and research, 2(10)129134

Oso, W.Y., \& Onen, D. (2009). A General Guide to writing research proposal and report: A handbook for beginning researchers. Nairobi: Jomo Kenyatta Foundation.

Page, B.,\& Hansen, S. (2008).Effective Team Leadership Learning to Lead Through Relationship. Nairobi Evangel Publishing House.

Peter, G. A. M. (2015). Relationship between Leadership Styles used by Head teachers of Public Secondary Schools and Students' Academic Performance. International Journal of Academic Research in Business and Social Sciences, 5(7), 2222-6990.

Peter, B. N. (2016). Analysis of Family Structure Influence on Academic Performance among Secondary School Students in Bungoma East Sub-County, Kenya. International Journal of Secondary Education. 4(2), $12-22$.

Petrie, K. (2014). The relationship between school climate and student bullying. TEACH J. Christ. Educ. $\quad 8, \quad 26-35 . \quad$ Available online at: https://research.avondale. edu.au/cgi/viewcontent.cgi?referer=https://scholar.google.com.au/\&https\%20redir=1\&art icle $=1237 \&$ context $=$ teach

Petty, N. W.,\& Green, T. (2007). Measuring educational opportunity as perceived by students: a process indicator. School Effectiveness and School Improvement, 18:67-91.

Price, H. (2008). Mobilizing the community to help students succeed. Alexandria, VA: Association for Supervision and Curriculum Development.

Republic of Kenya, (2016). Economic Survey 2016. Nairobi, Kenya National Bureau of Statistics.

Ralph, B.,\& McNeal J. (2014).Parent Involvement, Academic Achievement and the Role of Student Attitudes and Behaviors as Mediators. Universal Journal of Educational Research, 2(8), 564-576. 
Seashore, L.K., \& Leithwood,K. (2010). Leadership: investigating the links to improved student learning.Minesota: University of Minesota.

Sergon, D. (2005, October 6). School Success Depends on the Head Teacher's Ability. The

Standard. Nairobi: The Standard Group.

Sermon, J. M. (2005).Principals' relationship with computer technology. ASSP Bulletin, 89(643), 45-63. Policy Institute.

Siringi, S. (2010, March 3). KCSE: Year of the boys.

Smith, P. A., \& Hoy, W. K. (2007). Academic optimism and student achievement in urban elementary schools. J. Educ. Administrat, 45, 556-568. doi:10.1108/09578230710778196

Stavros, D., Nikolaos, B., George, A., \& Apostolos, V. (2016). Organizational Change Management: Delineating Employee Reaction to Change in SMEs Located in Magnesia. Academic Journal of Interdisciplinary Studies, 5(1), 309-317

Suleman, Q., Aslam, H. D., Hussain, I.,\& Shakir, M. (2012). Effects of Parental Socioeconomic Status on the Academic Achievement of Secondary School Students in District Karak (Pakistan). International Journal of Human Resource Studies, 2(4): 14-26.

Sushila, S.J. (2002). Factors affecting Students Performance in Kenya Certificate of Secondary Education examination in Public Secondary Schools in Maseno Division.M.Ed Research Project,UON: unpublished.

Tschannen-Moran, M., Parish, J., \& DiPaola, M. (2006). School climate: the interplay between interpersonal relationships and student achievement. J. Sch. Leadership, 16, 386.

Tsinidou, M., Gerogiannis, V., \& Fitsilis, P. (2010). Evaluation of the factors that determine quality in higher education: an empirical study. Quality Assurance in Education, 18(3), 227-244.

Twaweza East Africa, (2016). "A new dawn? Citizens views on new developments in education." Brief No. 30.

Twoli,N.W. (2006).Sex differences in science Achievement Among Secondary School in Kenya. Ph.D.Discertition. Australia. Flinders University of south Australia.

UNESCO. (2015). Education for all 2000-2015: Challenges and opportunities.

UNICEF. (2003). "UNICEF gloomy on child development goals." Lancet 362 (9400).

Wambui, A. (2015). Effectiveness of Guidance and Counseling Services in Secondary Schools in Kenya: A Case Study of Githunguri Sub-County in Kiambu County.American journal of education science, 1(4), 204-209.

Wammula, A. J. (2013). Factors influencing academic performance in Kenya.

Way, N., Reddy, R., \&Rhodes, J. (2007). Students' perceptions of school climate during the middle school y

ears: associations with trajectories of psychological and behavioral adjustment. Am. J. Community Psychol, 40, 194-213. doi: 10.1007/s10464-007-9143-y

Waseka, E. L., Simatwa, M.W., \& Okwach, T.O. (2016). Influence of teacher factors on students' academic performance in secondary school education. A case study of Kakamega County, Kenya. Greener Journal of Educational Research, 6(4), 151-169,

Wijsman, L. A., Warren, M. J., Saab, N. et al. (2016). Declining trends in student performance in lower secondary education. Eur J Psychol Edu, 31, 595-612

Williams, D. A. (2013). Strategic Diversity Leadership: Activating Change and Transformation in Higher Education. Sterling: Stylus Publishing. 